\title{
Effect of fruit size on physiological seed quality parameters of Cucumber (Cucumis sativus)
}

\section{P. Navitha}

Department of Seed Science and Technology, Agricultural College and Research Institute, Madurai-625 104 (Tamil Nadu), India

\section{K. Sujatha*}

Department of Seed Science and Technology, Agricultural College and Research Institute, Madurai-625 104 (Tamil Nadu), India

\section{A. Beaulah}

Department of Horticulture, Agricultural College and Research Institute, Madurai-625 104 (Tamil Nadu), India

${ }^{*}$ Corresponding author. E-mail: sujathakvk@gmail.com

\begin{abstract}
An experiment was carried out at the Department of Seed Science and Technology, Agricultural College and Research Institute, Madurai during 2018 to find out the effect of fruit size on physiological seed quality of cucumber. Variation in fruit size of cucumber results in poor quality seeds. In order to overcome this obstacle fruit grading was done based on weight of fruit to obtain good quality seeds. Harvested fruits of cucumber (Cucumis sativus) were categorized based on the weight into three different groups viz., Big $(2.41 \mathrm{~kg})$, medium $(1.66 \mathrm{~kg})$ and small $(1.28 \mathrm{~kg})$. Observations on fruit and seed quality parameters were recorded. The results revealed that medium sized fruits recorded higher values compared to big and small sized fruits. The number of seeds/fruit recorded higher in medium sized fruit (935 numbers) followed by small (896 numbers) and big ( 876 numbers) sized fruits. The big, medium and small fruits were recovered to $1.52 \%, 1.06 \%$ and $0.58 \%$ seeds respectively. The physiological quality characters measured in terms of seed germination revealed that seeds of medium sized fruits were recorded higher $(80 \%)$ followed by seeds of big ( $82 \%)$ and small $(65 \%)$. The seedling vigour measured through root $(17.08 \mathrm{~cm})$ and shoot length $(14.45 \mathrm{~cm})$, dry matter production $\left(0.85 \mathrm{~g} 10\right.$ seedlings $\left.^{-1}\right)$ and vigour index (2522) also proved the superiority in medium sized fruits.
\end{abstract}

Keywords: Cucumber, Fruit size, Germination, Vigour, Seed quality

\section{Article Info}

DOI:10.31018/jans.v11i2.2046 Received: March 22, 2019

Revised: May 15, 2019

Accepted: May 24, 2019

\section{How to Cite}

Navitha, P. et al. (2019). Effect of fruit size on physiological seed quality parameters of Cucumber (Cucumis sativus). Journal of Applied and Natural Science, 11(2): 394- 397 https://doi.org/10.31018/ jans.v11i2.2046

\section{INTRODUCTION}

Cucumber (Cucumis sativus L.) belongs to family Cucurbitaceae with chromosome number $(2 n=14)$ and originated in India (De Candole, 1967). It is commonly a monoecious, annual, trailing or climbing vine (Bailey, 1969). Cucumber is one of the most popular and widely grown vegetable all over India. It belongs to the family cucurbitaceae and is reported to have originated in India. It is one of the quickest maturing vine vegetable crop and is the second most widely cultivated cucurbit after watermelon. Cucumbers are good sources of phytonutrients, flavanoids, lignans and triterpenes which has antioxidant, anti-inflammatory and anticancer properties (Jessie Szalay, 2017)

Quality seeds ensures a successful crop production and the yield may be increased upto $15-20 \%$ (Ambika et al., 2014). The production environment and cultivation practices play a major role in variation in seed size, weight and density. Fruit size and shape were acknowledged as one of the most important quality parameter of all agricultural produce and also it define market and influence value of consumer expectations. Variability in fruit size and shape may be reflects in germination, seedling emergence and yield. Because of the fact that farmers hardly grade the cucumber fruits based on size before extraction. The cucurbit seeds used as planting material are derives from fruits of varying sizes. The varying level of fruit sizes also has contributed to the poor seed quality currently experienced which has resulted to the adoption of a higher seed rate. A significant correlation was reported between fruit weight and number of good seeds in pumpkin (Geetharani et al., 2007), in squash (Nerson, 2007) and in melon (Kortse et al., 2012).

However, non availability of quality seed has been a major constraint for seed production. Factors like stage of harvesting, fruit size, extraction methods, grading and storage conditions affect the 
production of the crop. One of the important ways to improving seed quality in terms of stage of harvest and processing the seed based on size and density. Scanty information is available in literature about fruit size on physiological seed quality. Keeping this in view, the present investigation was carried out to find the influence of fruit size on physiological seed quality in cucumber (Cucumis sativus).

\section{MATERIALS AND METHODS}

The experiment was carried out at Department of Seed Science and Technology, Agricultural College and Research Institute, Madurai during September 2018. The matured fruits at harvest were categorized visually into three sizes viz., big, medium and small based on fruit weight as $>2.00 \mathrm{~kg}$, $1.50 \mathrm{~kg}-2.00 \mathrm{~kg}$ and $<1.50 \mathrm{~kg}$ respectively. A total number of twenty five fruits in each grade were taken in five replications (5 fruits /replication). The observations on fruit length $(\mathrm{cm})$, girth $(\mathrm{cm})$ were recorded. After the seed extraction (seeds extracted from fruits using Hydrochloric acid - $0.5 \%$ ) the total number of seeds/fruit, seed weight (g), 100 seed weight $(\mathrm{g})$ and seed recovery $(\%)$ were recorded. The seeds were graded with BSS 8 wire mesh sieve (British standard sieve) and the physiological quality parameters viz., germination percentage (ISTA, 2011), root length $(\mathrm{cm})$, shoot length $(\mathrm{cm})$, dry matter production $(\mathrm{mg} / 10$ seedlings) and vigour index (Abdul - Baki and Anderson, 1973)were recorded.

The data were analysed after Snedecor and Cochran (1967). The Percentage values (germination values) were transformed to arc sine values wherever necessary.

\section{RESULTS AND DISCUSSION}

The results were highly significant for all observed characters. Fruit weight, length, girth and number of seeds per fruit were increased significantly with increase in fruit weight. Big sized fruits recorded higher fruit length $(37.50 \mathrm{~cm})$ compared to medium $(33.00 \mathrm{~cm})$ and small $(24.00 \mathrm{~cm})$. The fruit girth was also higher in big sized fruit $(34.00 \mathrm{~cm})$ followed by medium $(30.00 \mathrm{~cm})$ and small $(27.50 \mathrm{~cm})$ (Fig. 1)

On fruit grading the highest recovery of $1.52 \%$ was obtained with medium sized fruits which was followed by big sized fruit $(0.58 \%)$ and small sized fruits $(0.02 \%)$ (Fig. 3). The variation in fruit size may be due to flow of nutrients into the fruits of the mother plant. The fruit characters recorded with medium sized fruits were higher than big and small sized fruits. The small fruits had the least physical expressions. Similar positive association between fruit size and its physical characters were reported by Geetharani, (2007) in pumpkin and Venudevan et al., 2013 in bael.

The seed morphological characters viz., seed

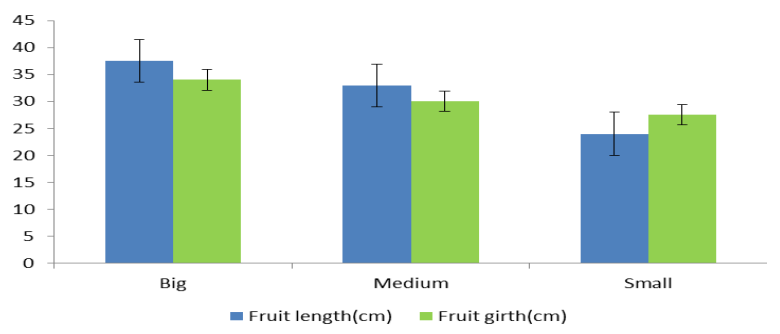

Fig. 1. Influence of fruit size on fruit length and fruit girth of cucumber (Cucumis sativus).

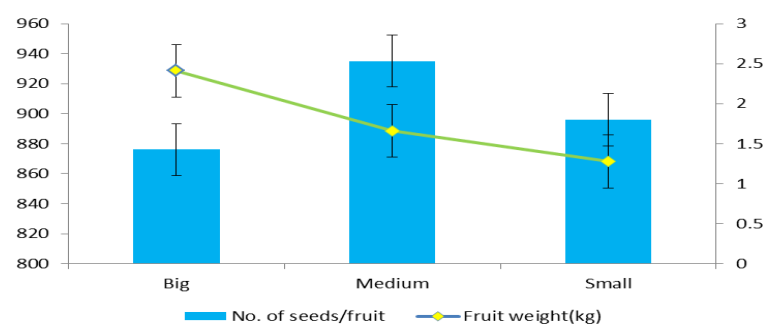

Fig. 2. Influence of fruit size on number of seeds and fruit weight of cucumber (Cucumis sativus).

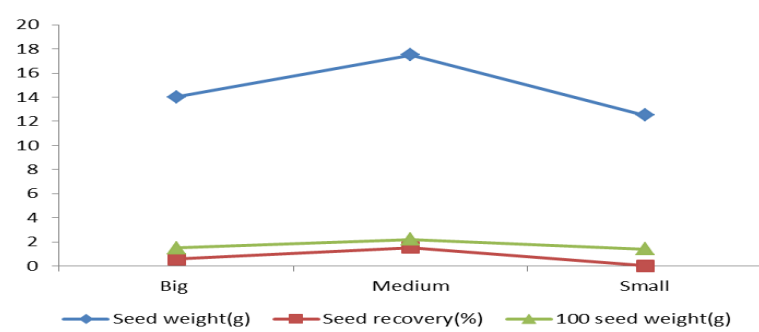

Fig. 3. Influence of fruit size on seed morphological characters of cucumber (Cucumis sativus).

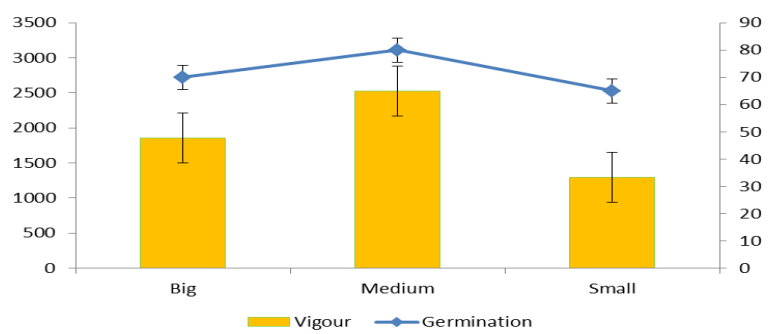

Fig. 4. Influence of fruit size on germination and vigour index of cucumber (Cucumis sativus).

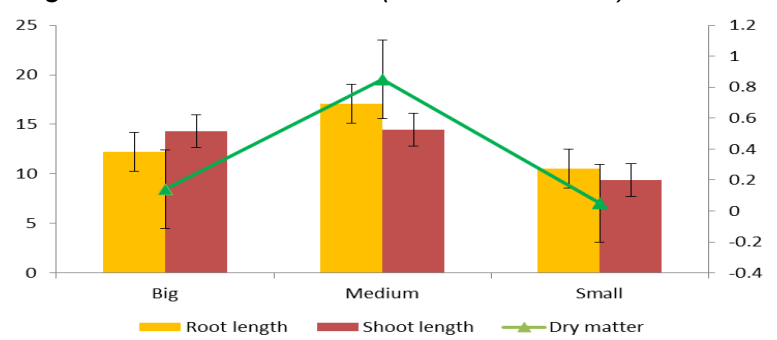

Fig. 5. Influence of fruit size on shoot length, root length and dry matter production of cucumber (Cucumis sativus).

weight/fruit $(17.5 \mathrm{~g}), 100$ seed weight $(2.2 \mathrm{~g})$ and number of seeds /fruit (935 numbers) were also higher in medium sized fruits and was followed by small sized fruit (Fig. 2). 
Big sized fruits do not exhibit the advantage of more seeds per fruit because ovules at the peduncle end are not fertilized and also have a strong tendency to parthenocarpy and produce high proportion of unfertilized ovules (or) empty seeds. The higher seed weight, 100 seed weight and number of seeds /fruit may be due to medium sized fruit have greater nutritional support (Nerson, 2005; Geetharani, 2007). Similar results were also reported by Singh and Rao, (1996) in rape; Srimathi, (1997) in amla and jamun; Srimathi et al., (1998) in ber and Venudevan et al., (2013) in bael.

The physiological quality evaluated through germination, root and shoot length, dry matter production and vigour index values were steadily coincided with fruit size. Dharmalingam and Vijayakumar (1987) in acid lime; Jerlin and Srimathi, (1999) in soapnut (Sapindus emerginatus); Mini et al. (2000) in ashgourd and Venudevan et al. (2013 in bael.

The medium sized fruits recorded higher germination $(80 \%)$ followed by big $(80 \%)$ and small sized fruits $(65 \%)$ (Fig. 4). The medium sized fruits recorded higher values of root length $(17.08 \mathrm{~cm})$, shoot length $(14.45 \mathrm{~cm})$, drymatter production $(0.85 \mathrm{~g} / 10$ seedlings) and vigour index (2522) than big and small fruits (Fig 5). Medium sized fruit seeds generally help in producing better seedling compared to big and small sized fruit seeds due to sufficient energy content in large sized fruits. Fruit and seed size is an important physical indicator of seed quality that affects vegetative growth, yield and market grade. It is a widely accepted measure of seed quality and different fruit and seed size affects seedling emergence, germination and other agronomical aspects (Kaydon and Yagmur, 2008). The nutrient content of the seeds depends on seed size and varies in species to species (Arunachalam et al., 2008)

Neverthless, heavy weighted seeds helps in producing better performance on seed germination survival and initial seedling growth compared to light weight seeds (Sadeghi et al., 2011 and Chanda et al., 2017).

Similar results were also reported by Malarkodi et al. (1999) in punnai; Kathiravan, (2004) in jatropha; Geetharani, (2007) in pumpkin and Venudevan et al. (2013) in bael. The better performance of seeds of medium sized fruits might be due to the initial capital theory and was expressed through the positive association between fruit size, seed size and the seed weight. The translocation of reserve from endosperm to embryo proceeds differently in large and small seeds.

\section{Conclusion}

The above study emphasized the need for size grading of cucumber (Cucumis sativus) fruits. It could be concluded that medium sized fruits may be selected for good crop establishment and also assurance is given for production of good quality seeds and produce vigorous seedlings.

\section{REFERENCES}

1. Abdul-Baki, A.A. and Anderson, J.D. (1973). Vigour determination of soybean seeds by multiple criteria. Crop Sci., 13: 630-633.

2. Ambika, S., Manonmani, V. and Somasundaram, G. (2014). Review on the effect of seed size on seedling vigor and yield. Res. J. Seed Sci., 1: 1-8.

3. Arunachalam, A., Khan, M.L. and Singh, N.D. (2003). Germination, growth and biomass accumulation as influenced by seed size in Mesua ferrea L. Turkish $\mathrm{J}$. Bot., 27: 343-8.

4. Bailey, L. H. (1969). Manual of cultivated plants. Macmillan company., New York: 116.

5. Chanda, S. C., Mridul, A.M., Sagar, A. and Sarwar, A. K. M. G. (2017). Germination and seedling growth of Sesbania species as influenced by seed size. Progressive Agriculture, 28(4): 316-322.

6. De Candole, A. 1967. Origin of Cultivated Plants. Hafnar Publishing Co., New York: 264.

7. Dharmalingam, C. and Vijayakumar, A. (1987). Seed quality in relation to fruit size in acid lime. S. Indian. Hort., 35: 274-279.

8. Geetharani, P., Vijayakumar, A., Geetha, R. and Natarajan, S. (2007). Effect of fruit size on seed quality characteristics of pumpkin. Madras Agric. J., 94 (712): 278-279.

9. ISTA, 2011. International rules for seed testing. International Seed Testing Association, Bassersdorf, Switzerland.

10.Jerlin, R. and Srimathi, P. (1999). Fruit selection for better seedling production in soap nut (Sapindus emerginatus). Trop. Agric. Res. Extension, 2: 126-128.

11.Jessie Szalay. (2017). Cucumbers: Health Benefits and Nutrition Facts. https://www.livescience.com /51 000-cucumber-nutrition.html.

12. Kathiravan, M. (2004). Seed production, processing, testing and storage techniques in Jatropha (Jatropha curcaslinn.). Ph.D. Thesis, Tamil Nadu Agricultural University, Coimbatore.

13.Kaydan, D. and Yagmur, M. (2008). Germination, seedling growth and relative water content of shoot in different seed size of triticale under osmotic stress of water and NaCl. African J. Biotechnol., 7: 2862-2868.

14.Kortse, P. A., Oladiran, J. A. and Msaakpa, T. S. (2012). Effects of season and fruit size on the quality of'egusi' melon [Citrullus lanatus (Thunb) Matsum and Nakai] seed. Journal of Agricultural and Biological Science, 7(2), 110-116.

15.Malarkodi, K., Srimathi, P., Sasthri, G. and Nelsonnavamaniraj, K. (1999). Maximisation of seed germination in punnai (Callophyllum inophyllum). Proceedings of the National Seminar on Seed Technology at Directorate of Agriculture and Government, Motilal Vigyan Mahavidyalaya, November 19-20, 1999, Bhopal (M.P.), pp: 114.

16.Mini, C., Meagle, P. and Rajan, S. (2000). Effect of fruit size on seed quality of ash gourd and cucumber. Seed Research., 28(2): 215- 6.

17.Nerson, H. (2005). Effects of fruit shape and plant density on seed yield and quality of squash. Scientia Horticulturae, 105(3), 293-304. 
Navitha, P. et al. / J. Appl. \& Nat. Sci. 11(2): 394- 397 (2019)

18.Nerson, H. (2007). Seed production and germinability of cucurbit crops. Seed Science and Biotechnology, 1(1), 1-10.

19.Sadeghi, H., Khazaei, F., Sheidaei, S. and Yari, L. (2011). Effect of seed size on seed germination behavior of safflower (Carthamus tinctorius L.). ARPN Journal of Agricultural and Biological Science., 6(4), 5-8.

20.Singh, B.G. and Rao, S.J. (1996). Influence of seed size on growth and yield in rape seed. Seed $R e-$ search., 22(2): 172-173.

21.Snedecor, G. W. and Cochran, W. G. (1967). Statistical Methods, Sixth-Edition.

22. Srimathi, P. (1997). Research focus on fruit col- lection, processing and storage in amla (Emblica officinalis), ber (Zizyphus mauritiana) and jamun (Syzygim cuminii). Ph.D. Thesis, Tamil Nadu Agricultural University, Coimbatore, India.

23. Srimathi, P., Karivaratharaju, T.V. and Malarkodi, K. (1998). Seed quality in relation to fruit size in ber (Zizyphus mauritiana). My Forest., 34: 933939.

24. Venudevan, B., Srimathi, P., Natarajan, N. and Vijayakumar, R.M. (2013). Influence of fruit polymorphism on seed and seedling quality characters of Bael (Aegle marmelos) the endangered medicinal tree. Asian J. Crop Sci., 1-7. 